\title{
Effect of four different tillage practices on maize performance under rainfed conditions
}

\author{
${ }^{1}$ S.H.M. Aikins, ${ }^{2}$ J.J. Afuakwa and ${ }^{1}$ O. Owusu-Akuoko \\ ${ }^{1}$ Department of Agricultural Engineering, College of Engineering, \\ Kwame Nkrumah University of Science \& Technology, Kumasi, Ghana. \\ ${ }^{2}$ Department of Agroforestry, College of Agriculture and Natural Resources, \\ Kwame Nkrumah University of Science and Technology, Kumasi, Ghana. \\ Email: stevenaikins@yahoo.com; shmaikins.coe@knust.edu.gh
}

\begin{abstract}
An experiment was conducted on Ferric Acrisol under rainfed conditions during the 2010 minor crop growing season in Kumasi, Ghana to determine the effect of different tillage practices on Akposoe maize (Zea mays .L) variety performance. The experiment was arranged in a randomised complete block design with four treatments namely disc ploughing only, disc ploughing followed by disc harrowing, disc harrowing only and No Tillage. Each treatment was replicated three times. At ten weeks after planting, the disc harrowing only plots produced the tallest plant, biggest stem girth, highest number of leaves per plant, and highest leaf area index. On the other hand the No Tillage plots presented the shortest plant, smallest stem girth, lowest number of leaves per plant, and smallest leaf area index. At harvest, the longest root, highest dry matter yield and highest fresh cob weight were obtained from the disc harrowing only plots while the shortest root, lowest dry matter yield, lowest fresh cob weight, lowest dry cob weight, and smallest 1000 -seed weight were located in the No Tillage plots. The disc ploughing followed by disc harrowing treatment produced the highest dry cob weight and highest 1000-seed weight. There was no significant difference in Akposoe maize plant growth, dry matter yield and yield components between the disc harrowing only and the disc ploughing followed by disc harrowing treatments. Thus, considering the soil and weather conditions of the experiment, the optimum tillage practice for producing Akposoe maize variety is disc harrowing only.
\end{abstract}

Keywords: Tillage, maize, growth, dry matter yield, yield components.

\section{INTRODUCTION}

Maize (Zea mays, L.) is an important cereal crop worldwide. It is the most important cereal crop in Ghana and is an important component of sustainable cropping systems in the country contributing significantly to household food security. The crop is consumed by people with varying food preferences and socioeconomic backgrounds in Ghana (BaduApraku et al., 2011). The area harvested to maize in Ghana in 2009 was 954,400 Ha (FAO Statistical Databases, 2011). Maize is a versatile crop, allowing it to grow across a range of agro-ecological zones in Ghana except for the Sudan savannah (Morris et al., 1999). A number of factors constrain maize production in Ghana including declining soil fertility, little or inadequate use of chemical fertilisers, poor weed and pest controls, and inappropriate tillage practices.
In Ghana, maize is largely grown by resource poor smallholder farmers under rainfed conditions. These farmers employ different tillage practices in the production of the crop. While some farmers plant maize after disc ploughing without disc harrowing, other farmers disc plough and disc harrow before planting. There are some farmers who disc harrow without disc ploughing before planting. Some farmers "slash and burn" while others use no tillage before planting maize. Many farmers perform tillage operations without being aware of the effect of these operations on soil physical properties and crop responses (Ozpinar and Isik, 2004). Tillage is one of the important processes in agriculture. It is carried out mainly to loosen the upper layer of soil, to mix the soil with fertiliser and organic residues, to control weeds, and to create a suitable seedbed for germination and plant growth (Rasmussen, 1999). According to Srivastava et al. (2006), the objectives 
of tillage are to develop a desirable soil structure or suitable tilth for a seedbed. Tillage is crucial for crop establishment, growth and ultimately, yield (Atkinson et al., 2007). A good soil management programme protects the soil from water and wind erosion, provides a good, weed-free seedbed for planting, destroys hardpans or compacted layers that may limit root development, and allows maintenance or even an increase of organic matter (Wright et al., 2008).

Tillage systems are site specific and depend on crop, soil type and the climate (Rasmussen, 1999). Tillage practices influence soil physical, chemical and biological characteristics, which in turn may alter plant growth and yield (Çarman, 1997; Ozpinar and Cay, 2006; Rashidi and Keshavarzpour, 2009). Different tillage practices may affect the growth and yield of maize due to different soil conditions created. But there is inadequate information on the effect of tillage practices on maize growth and yield in the humid zone of Ghana. The objectives of the study was to compare the effect of four different tillage practices on the growth, dry matter yield and yield components of Akposoe maize variety.

\section{MATERIALS AND METHODS}

Description of the Study Location: This study was conducted under rainfed conditions at the arable field of the Plantation Section of the Department of Crop and Soil Sciences at Kwame Nkrumah University of Science \& Technology in Kumasi (latitude $6^{\circ} 41^{\prime} 00^{\prime \prime} \mathrm{N}$, longitude $1^{\circ} 33^{\prime} 3^{\prime \prime} \mathrm{W}$ and altitude $296.6 \mathrm{~m}$ above sea level) during the 2010 minor crop growing season. The study site is located in the semi deciduous forest agro-ecological zone of Ghana. The study area had been previously sown to groundnut (Arachis hypogea, L.) for two years, maize (Zea mays, L.) for one year and cowpea (Vigna unguiculata [L.] Walp) for one year prior to starting the experiment. The soil at the site is Ferric Acrisol (Adu, 1992; FAO, 1998) [(Paleustult in USDA Classification)] with sandy loam texture in the $0-15 \mathrm{~cm}$ layer overlain with loam texture in the $15-30 \mathrm{~cm}$ layer. Table 1 presents some properties of the soil at the study area prior to starting the experiment. Mean annual rainfall and temperature are $1300 \mathrm{~mm}$ and $26^{\circ} \mathrm{C}$, respectively. Weather data during the experimental period is summarized in Table 2.

Experimental Design and Treatments: The experiment was arranged in a randomised complete block design (RCBD) with four tillage treatments in three replicate blocks. The treatments included disc ploughing only, disc-ploughing followed by disc harrowing, disc-harrowing only and no tillage. Each plot measured $3.0 \times 3.5 \mathrm{~m}$.

Table 1: Soil Properties at the Experimental Site

\begin{tabular}{|c|c|c|}
\hline & \multicolumn{2}{|c|}{ Soil layer $(\mathrm{cm})$} \\
\hline Soil Property & $0-15$ & $15-30$ \\
\hline Sand (\%) & 68.04 & 52.10 \\
\hline Silt (\%) & 13.96 & 33.90 \\
\hline Clay (\%) & 18.00 & 14.00 \\
\hline $\begin{array}{ll}\text { Organic } & \text { Carbon } \\
(\%) & \\
\end{array}$ & 1.58 & 1.51 \\
\hline Organic Matter (\%) & 2.72 & 2.60 \\
\hline $\mathrm{pH}$ & 5.20 & 5.20 \\
\hline Total N & 0.15 & 0.14 \\
\hline $\mathrm{Ca}\left(\mathrm{cmol} \mathrm{kg}^{-1}\right)$ & 5.07 & 4.54 \\
\hline $\mathrm{Mg}\left(\mathrm{cmol} \mathrm{kg}^{-1}\right)$ & 1.60 & 1.34 \\
\hline $\mathrm{K}\left(\mathrm{cmol} \mathrm{kg}^{-1}\right)$ & 0.83 & 0.42 \\
\hline$\underset{4}{\left.{ }_{1}\right)} \mathrm{NH}_{4}^{+} \mathrm{N} \quad\left(\mathrm{cmol} \mathrm{kg}^{-}\right.$ & 64.00 & 43.69 \\
\hline $\begin{array}{l}\text { Available } P \quad(\mathrm{cmol} \\
\left.\mathrm{kg}^{-1}\right)\end{array}$ & 21.85 & 15.55 \\
\hline $\mathrm{Na}\left(\mathrm{cmol} \mathrm{kg}^{-1}\right)$ & 0.46 & 0.42 \\
\hline
\end{tabular}

Table 2: Temperature and Rainfall at the Experimental Site

\begin{tabular}{|l|c|c|c|}
\hline Month & $\mathrm{T}_{\max }\left({ }^{\circ} \mathrm{C}\right)$ & $\mathrm{T}_{\min }\left({ }^{\circ} \mathrm{C}\right)$ & Rainfall $(\mathrm{mm})$ \\
\hline October & 31.0 & 22.0 & 163.3 \\
\hline November & 31.5 & 22.5 & 111.1 \\
\hline December & 32.4 & 22.0 & 47.0 \\
\hline
\end{tabular}

$\mathrm{T}_{\max }\left({ }^{\circ} \mathrm{C}\right)$ Maximum Air Temperature; $\mathrm{T}_{\min }\left({ }^{\circ} \mathrm{C}\right)$ Minimum Air Temperature

Cultural Practices: Akposoe maize, an extra early maturing variety (80-85 days), was sown at two seeds per hill at a depth of $5 \mathrm{~cm}$ with a customized depth controlled dibbler (Aikins et al., 2006). Plant spacing of $75 \mathrm{~cm}$ by $35 \mathrm{~cm}$ was used giving a plant population of 76,190 plants/ha. Weed control was carried out at 2 and 5 weeks after planting (WAP). Weeds in the conventional tillage plots were controlled using a hand hoe while those in the No Tillage plots were controlled using Anitraz 500 S.C. herbicide at a rate of one litre per hectare mixed in 200 litres of clean water. Insect pests were controlled with KILSECT 2.5 E.C. insecticide containing $25 \mathrm{~g}$ of Lambda-cyhalothrin per litre at a rate of one litre per hectare mixed in 200 litres of clean water and applied at 2, 5, and 7 WAP.

Data Collection: Six plants were tagged per plot for the determination of growth, dry matter yield and yield components. Plant height, stem girth, number of leaves per plant, and leaf area index were measured 
at weekly intervals for ten weeks beginning at one week after planting. Root length, dry matter yield, fresh cob weight, dry cob weight and 1000-Seed weight were determined at harvest. Plant height was measured as the vertical distance between the ground and the highest living part of the plant with a ruler/metre rule. Stem girth was measured using a white thread and a ruler. Number of leaves per plant was determined by counting all the leaves on each plant. The mean of the six plants was used as the number of leaves per plant. In order to determine the leaf area index, the length and width of the leaves on a plant were measured with a ruler. The leaf area index was calculated using equation 1:

\section{Leaf Area Index $=k(L x W)$ \\ Equation 1}

where

$k=0.75$ which is constant for all cereals

$L=$ Leaf length,

$W=$ Leaf width

At harvest, the six tagged plants per plot were manually harvested, washed and cleaned to remove traces of soil. Root length was measured with a ruler. The above-ground biomass of the plants were placed in brown envelopes and oven dried at $70^{\circ} \mathrm{C}$ for 48 hours. The dry weights were measured with an electronic balance. Fresh cob weight, dry cob weight, and 1000-seed weight were also measured using an electronic balance.

Data Analysis: Statistical analysis of data was conducted using the Balanced Analysis of Variance (ANOVA) procedure in MINITAB Statistical Software Release 15 (MINITAB Inc., 2007). The Least Significant Difference (LSD) test was determined at $p$ $<0.05$ to pinpoint significant difference between treatment means.

\section{RESULTS AND DISCUSSION}

Plant Height: The height of the plants for each tillage practice is shown in Fig. 1. Over the course of the study, analysis of variance showed no significant difference in plant height between the different tillage treatments except for that of the fourth week after planting. At 10 weeks after planting, the tallest plant was located in the disc harrowing only plots while the shortest plant was found in the No Tillage plots. These results are similar to that of Kayode and Ademiluyi (2004) who observed the shortest maize plant in the No Tillage plots in comparison with that in the tilled plots on a sandy clay loam alfisol in Southwestern Nigeria. Khurshid et al. (2006) also reported taller plants in conventional tillage plots in comparison with that of the Minimum tillage plots in Faisalabad, Pakistan. Aikins and Afuakwa (2010) also reported taller cowpea plants in the tilled plots compared that of the No Tillage plots. In contrast, Ojeniyi and Adekayode (1999) reported taller maize plants in the No Tillage plots in comparison with that of the tilled plots except for that in the ploughing followed by harrowing plus ridging plots on sandy clay loam soil (Ferric Luvisol) at Akure, located in the rainforest zone of Nigeria. They reported no significant difference in plant height between the indicated treatments.

Stem Girth: Stem girth is an expression of vegetative growth (Squire, 1990). Fig. 2 presents results of the effect of tillage practices on Akposoe maize stem girth. At 10 weeks after planting there was no significant difference in stem girth between the different tillage practices. Overall, the biggest Akposoe maize variety plant stem girth was observed in the disc harrowing only plots. The second biggest stem girth was located in the disc ploughing followed by disc harrowing plots. This was followed by that of the disc ploughing only plots. The smallest stem girth was found in the No Tillage plots. Similar results were obtained by Aikins and Afuakwa (2010) for cowpea.

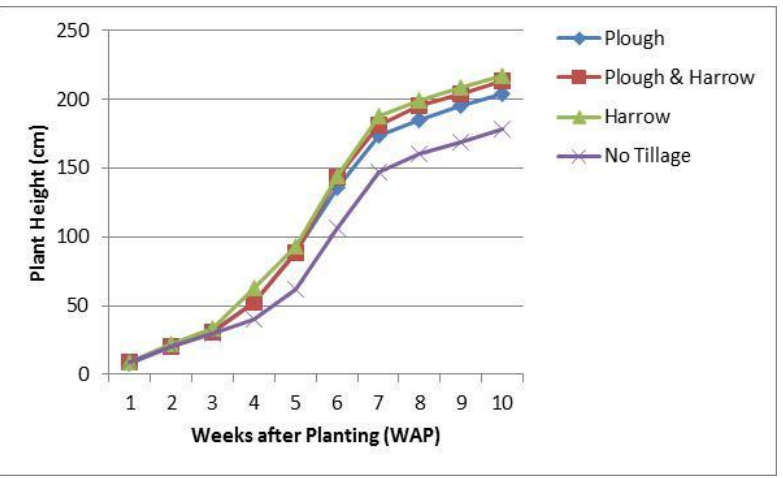

Fig. 1: Effect of tillage practice on plant height

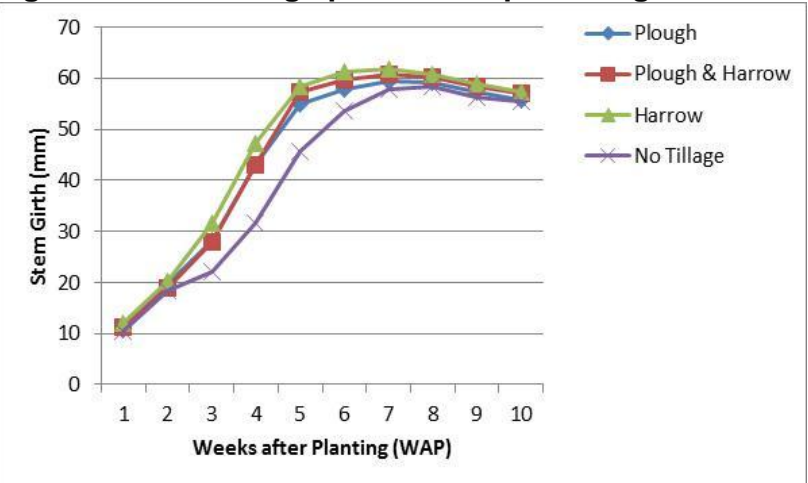

Fig. 2: Effect of tillage practices on stem girth 


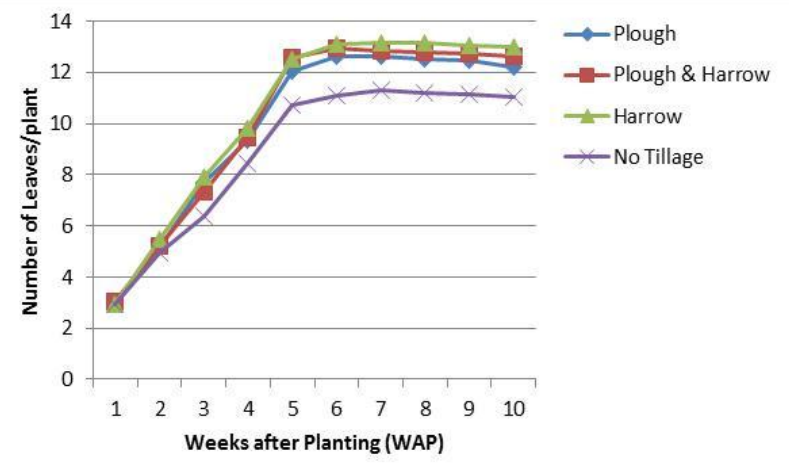

Fig. 3: Effect of tillage practices on number of leaves per plant

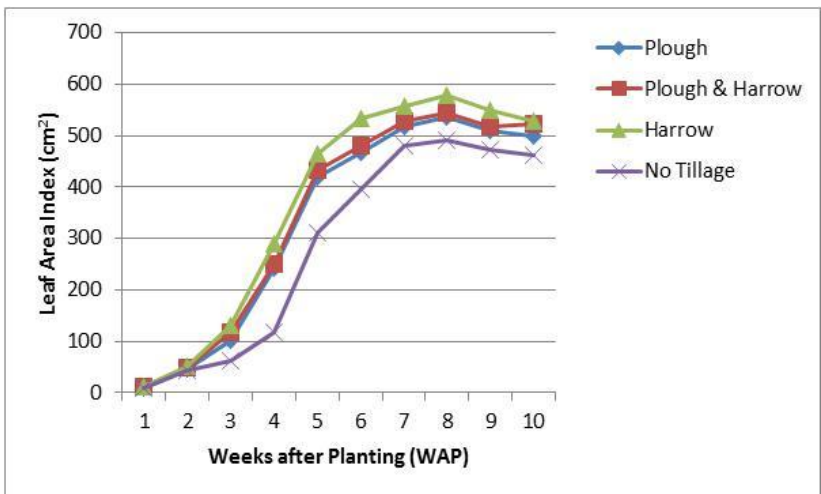

Fig. 4: Effect of tillage practices on leaf area index

Number of Leaves per Plant: Leaves are the site of photosynthetic activities of crops through which biomass are produced, partitioned among various parts of crops and stored for crop productivity (Asare et al., 2011). Fig. 3 illustrates the effect of the different tillage practices on Akposoe maize number of leaves per plant. There was significant effect of tillage practices on Akposoe maize number of leaves per plant except for the first, second and fourth weeks after planting. At 10 weeks after planting, the disc harrowing only plots produced the highest number of leaves per plant. The disc ploughing followed by disc harrowing treatment produced the second highest number of leaves per plant. This was followed by the disc ploughing only treatment. The No Tillage plots presented the lowest number of leaves per plant significantly lower than that of all the other treatments. There was no significant difference in number of leaves per plant between the disc ploughing followed by disc harrowing and that of the disc ploughing only treatments.
Leaf Area Index: Maize leaf area is of importance to photosynthesis and yield. The photosynthetic capacity of crops is a function of leaf area. Leaf area is important for crop light interception and therefore has a large influence on crop yield (Dwyer and Stewart, 1986). Fig. 4 depicts the effect of tillage practices on Akposoe maize leaf area index over the course of the study. There was no significant effect of tillage practices on Akposoe maize leaf area index except for that at one and four weeks after planting respectively. At 10 weeks after planting, the disc harrowing only treatment produced the highest leaf area index in comparison with the other treatments. The disc ploughing followed by the disc harrowing treatment gave the next highest leaf area index. This was followed by the disc ploughing only treatment. The No tillage plots produced the smallest leaf area index.

Root Length and Dry Matter Yield: Table 3 gives the Akposoe maize root length and dry matter yield at harvest. The disc ploughing followed by disc harrowing treatment presented the longest root. There was no significant difference in root length between the three tilled treatments. The No Tillage treatment produced Akposoe maize root length significantly shorter than that of the three tilled treatments. The results are similar to that of Materechera and Mloza-Banda (1997) who reported significantly lower maize root length density in the 0$20 \mathrm{~cm}$ depth in the minimum ridge-tillage system compared with that in the conventional ridge-tillage system. Optimum crop yields are dependent on optimum root growth, and when soil is in good condition, root systems are large, deep, and expansive (Trousse, 1977 cited by Abu-Hamdeh, 2003).

Table 3 also shows that the highest dry matter yield was found in the disc harrowing only plots while the lowest Akposoe maize dry matter yield was located in the No Tillage plots. There was no significant effect of tillage practices on dry matter yield. These results are similar to that of Díaz-Zorita (2000) who reported higher dry matter yield in conventional tillage plots in comparison with that of the No Tillage plots on a sandy loam Typic Hapludoll soil in Buenos Aires, Argentina.

Fresh Cob Weight, Dry Cob Weight and 1000Seed Weight: The effect of tillage practices on fresh cob weight, dry cob weight, and 1000-seed weight at 
harvest are summarized in Table 4 . The No Tillage treatment presented the lowest fresh cob weight, dry cob weight, and 1000-seed weight in comparison with the other tillage treatments. The disc harrowing only treatment produced the highest fresh cob weight while the disc ploughing followed by disc harrowing treatment produced the highest dry cob weight, and 1000 -seed weight. However, there was no significant effect of tillage practices on fresh cob weight, dry cob weight, and 1000-seed weight between the different tillage practices. The lowest fresh cob weight, dry cob weight, and 1000-seed weight obtained in the No Tillage plots may be due to the lack of soil loosening for providing conditions favourable to crop growth and yield. These results are in agreement with that of Videnović et al. (2011) who observed higher maize yield in conventional tillage plots in comparison with that of the No Tillage plots on the chernozem soil type in Zemun Polje, Serbia. Ishaq et al. (2001) reported higher wheat grain yield under conventional tillage as compared with that under minimum tillage on sandy clay loam soil (Luvic Yermosol) in Faisalabad in the semi-arid region of Pakistan.

Table 3: Root Length and Dry Matter Yield at Harvest

\begin{tabular}{|l|c|c|}
\hline Treatment & $\begin{array}{c}\text { Root Length } \\
(\mathrm{cm})\end{array}$ & $\begin{array}{c}\text { Dry Matter } \\
\text { Yield }\left(\mathrm{kg} \mathrm{ha}^{-1}\right)\end{array}$ \\
\hline Plough & 31.1 & 3322 \\
\hline $\begin{array}{l}\text { Plough \& } \\
\text { Harrow }\end{array}$ & 32.4 & 3409 \\
\hline Harrow & 31.9 & 3808 \\
\hline No Tillage & 22.1 & 2717 \\
\hline Average & 29.4 & 3314 \\
\hline LSD at 0.05 & 2.0 & $\mathrm{~ns}^{*}$ \\
\hline
\end{tabular}

ns* not significant

Table 4: Fresh Cob Weight, Dry Cob Weight, and 1000Seed Weight

\begin{tabular}{|l|c|c|c|}
\hline Treatment & $\begin{array}{c}\text { Fresh Cob } \\
\text { Weight }(\mathrm{g})\end{array}$ & $\begin{array}{c}\text { Dry Cob } \\
\text { Weight }(\mathrm{g})\end{array}$ & $\begin{array}{c}1000-\text { Seed } \\
\text { Weight }(\mathrm{g})\end{array}$ \\
\hline Plough & 7365 & 300 & 156 \\
\hline $\begin{array}{l}\text { Plough \& } \\
\text { Harrow }\end{array}$ & 7704 & 356 & 186 \\
\hline Harrow & 9312 & 348 & 165 \\
\hline No Tillage & 6519 & 246 & 149 \\
\hline Average & 7725 & 313 & 164 \\
\hline LSD at 0.05 & $\mathrm{~ns}$ & $\mathrm{~ns}$ & $\mathrm{~ns}$ \\
\hline
\end{tabular}

\section{CONCLUSION}

This study examined the effect of four different tillage practices on Akposoe maize performance. Based on the results obtained, the following conclusions are drawn: the disc harrowing only plots produced the tallest plant, biggest stem girth, highest number of leaves per plant, highest leaf area index, longest root, highest dry matter yield and highest fresh cob weight. On the other hand the No Tillage plots presented the shortest plant, smallest stem girth, lowest number of leaves per plant, smallest leaf area index, shortest root, lowest dry matter yield, lowest fresh cob weight, lowest dry cob weight, and smallest 1000-seed weight. The disc ploughing followed by disc harrowing treatment produced the highest dry cob weight and highest 1000 -seed weight. There was no significant difference in Akposoe maize plant growth, dry matter yield and yield components between the disc harrowing only and the disc ploughing followed by disc harrowing treatments. Thus, considering the soil and weather conditions of the experiment, the optimum tillage practice for producing Akposoe maize variety is disc harrowing only.

\section{ACKNOWLEDGMENT}

The authors are sincerely thankful to Crops Research Institute (CRI) of the Council for Scientific and Industrial Research (CSIR), Ghana for kindly providing the Akposoe maize seeds for the experiment.

\section{REFERENCES}

Abu-Hamdeh, N.H. (2003).Compaction and Subsoiling Effects on Corn Growth and Soil Bulk Density, Soil Science Society of America Journal. 67:1213-1219.

Adu, S.V. (1992). Soils of the Kumasi Region, Ashanti Region, Ghana. Memoir No. 8. CSIR-Soil Research Institute, Kwadaso, Kumasi.

Aikins, S.H.M. and Afuakwa, J.J. (2010). Effect of Four Different Tillage Practices on Cowpea Performance, World Journal of Agricultural Sciences. 6 (6): 644-651.

Aikins S.H.M., Afuakwa, J.J. and Baidoo, D. (2006). Effect of Planting Depth on Maize Stand Establishment. Journal of the Ghana Institution of Engineers. 4(2): 2025.

Asare, D.K., Frimpong, J.O. and Ayeh, E.O. (2011). Analysis of Leaf Parameters of Rainfed Maize Cultivars, American-Eurasian Journal of Agricultural and Environmental Sciences. 10 (3): 338-345.

Atkinson, H.S., Sparkes, D.L. and Mooney, S.J. (2007). Using selected soil physical properties of seedbeds to predict crop establishment, Soil and Tillage Research. 97(2): 218-228.

Badu-Apraku, B., Akinwale, R.O., Menkir, A., Obeng-Antwi, K., Osuman, A.S., Coulibaly, N., Onyibe, J.E., Yallou, G.C., Abdullai, M.S. and Didjera, A. (2011). Use of GGE Biplot for Targeting Early Maturing Maize Cultivars to Mega-environments in West Africa, African Crop Science Journal. 19(2): 79-96. 
Çarman, K. (1997). Effect of different tillage systems on soil properties and wheat yield in Middle Anatolia, Soil and Tillage Research. 40 (3-4): 201-207.

Díaz-Zorita, M. (2000). Effect of deep-tillage and nitrogen fertilization interactions on dryland corn (Zea mays L.) productivity, Soil and Tillage Research. 54, (1-2): 1119.

Dwyer, L.M. and Stewart, D.W. (1986). Leaf Area Development in Field-Grown Maize, Agronomy Journal. 78:334-343.

FAO Statistical Databases (2011). FAOSTAT: Agriculture Data. Available online: http://faostat.fao.org/site/567/DesktopDefault.aspx?Pa gelD $=567$ \#ancor

FAO (1998). World reference base for soil resources. World Soil Resources Report 84, Food and Agriculture Organization of the United Nations, Rome.

Ishaq, M., Ibrahim, M. and Lal, R. (2001). Tillage effect on nutrient uptake by wheat and cotton as influenced by fertilizer rate, Soil and Tillage Research. 62 (1-2): 4153.

Kayode, J. and Ademiluyi, B. (2004). Effect of Tillage Methods on Weed Control and Maize Performance in Southwestern Nigeria Location, Journal of Sustainable Agriculture. 23(3): 39-45.

Khurshid, K., Iqbal, M., Arif, M.S. and Nawaz, A. (2006). Effect of tillage and mulch on soil physical properties and growth of maize, International Journal of Agriculture and Biology. 8 (5): 593-596.

Materechera, S.A. and Mloza-Banda, H.R. (1997). Soil penetration resistance, root growth and yield of maize as influenced by tillage system on ridges in Malawi, Soil and Tillage Research. 41 (1-2): 13-24.

MINITAB Inc. (2007). MINITAB Statistical Software Release 15 for Windows. Minitab Inc. State College, Pennsylvania.

Morris, M.L., Tripp R. and Dankyi, A.A. (1999). Adoption and Impacts of Improved Maize Production Technology. A Case Study of the Ghana Grains Development Project, Economics Program Paper 99-
01. Mexico, D.F., CIMMYT. Available online: http://www.cimmyt.org/Research/economics/map/rese arch_results/program_papers/pdf/EPP\%2099_01.pdf.

Ojeniyi, S.O. and Adekayode, F.O. (1999). Soil conditions and cowpea and maize yield produced by tillage methods in the rainforest zone of Nigeria, Soil and Tillage Research. 51: (1-2): 161-164.

Ozpinar, S. and Isik, A. (2004). Effects of tillage, ridging and row spacing on seedling emergence and yield of cotton, Soil and Tillage Research. 75 (1): 19-26.

Ozpinar, S. and Cay, A. (2006). Effect of different tillage systems on the quality and crop productivity of a clayloam soil in semi-arid north-western Turkey, Soil and Tillage Research. 88 (1-2): 95-106.

Rasmussen, K.J. (1999). Impact of ploughless soil tillage on yield and soil quality: A Scandinavian review, Soil and Tillage Research. 53(1): 3-14.

Rashidi, M. and Keshavarzpour, F. (2009). Effect of Different Tillage Methods on Grain Yield and Yield Components of Maize (Zea mays L.), International Journal of Agriculture and Biology. 9 (2): 274-277.

Squire, G.R. (1990). The physiology of tropical crop production, CAB International, Wallingford, United Kingdom.

Srivastava A.K.,Goering C.E., Rohrbach R.P. and Buckmaster D.R. (2006). Engineering Principles of Agricultural Machines. $2^{\text {nd }}$ Edition, American Society of Agricultural Biological Engineers, Michigan.

Trouse, A.C. (1977). Soil physical characteristics and root growth. p. 319-325. In The role of soil physical properties in maintaining productivity of tropical soils. Proc. Int. Inst. of Tropical Agriculture, Ibadan, Nigeria. IITA, Ibadan, Nigeria.

Videnović, Ž., Simić, M., Srdić, J. and Dumanović, Z. (2011). Long term effects of different soil tillage systems on maize (Zea mays L.) yields, Plant, Soil and Environment. 57 (4): 186-192.

Wright, D., Marois, J., Rich, J. and Sprenkel, R. (2008). Field Corn Production Guide - SS-AGR-85. Available online: http://edis.ifas.ufl.edu/pdffiles/AG/AG20200.pdf 